\title{
RECENT GLACIAL HISTORY OF AN ALPINE AREA IN THE COLORADO FRONT RANGE, U.S.A. I. ESTABLISHING A LICHEN-GROWTH GURVE
}

\author{
By James B. Benedict \\ (Institute of Arctic and Alpine Research, University of Colorado, Boulder, Colorado, U.S.A.)
}

\begin{abstract}
A lichen-growth curve has been developed for dating Recent glacial and periglacial deposits in the Indian Peaks area of the Colorado Front Range. Rhizocarpon geographicum was selected for the study because of its long life span and consistent size-age relationship. The species grows at different rates in different micro-environments, with moisture, stability of substrate and length of snow-free growing season having the greatest effect. Growth rates were determined indirectly, by measuring the maximum diameters of circular or nearly circular thalli growing on surfaces of known exposure age. Measurements were made on 24 historically dated surfaces, ranging in age from 25 to $69 \mathrm{yr}$., and on three radiocarbon-dated surfaces, including (1) mudflow levees younger than $180 \mathrm{yr} .,(2)$ a rock wall built by prehistoric Indians about $970 \mathrm{yr}$. ago, and (3) ground moraine deposited by a retreating valley glacier about 2,460 radiocarbon years ago. $R$. geographicum grows very rapidly ( $14 \mathrm{~mm}$./ $100 \mathrm{yr}$.) during the first $100 \mathrm{yr}$. of its life. Growth then slows to an average rate of $3.3 \mathrm{~mm}$./ $100 \mathrm{yr}$. The completed growth curve is believed to be suitable for dating deposits at least as old as 3,000 yr.
\end{abstract}

RÉsumé. Histoire glaciaire récente d'une zone alpine de Colorado Front Range, U.S.A. I. Etablissement d'une courbe de croissance des lichens. Une courbe de croissance des lichens a été établie pour dater les dépôts glaciaires récents et périglaciaires dans les Indian Peaks, Colorado Front Range. On a choisi Rhizocarpon geographicum pour cette étude à cause de l'étendue de sa longue vie et de la consistence de la relation entre âge et dimension. Cette espèce croît, à différentes vitesses dans différentes conditions micro-climatologiques, l'humidité, la stabilité du substratum, et la durée de la saison de croissance libre de neige ayant le plus grand effet. Les vitesses de croissance ont été déterminées indirectement, en mesurant les diamètres maximum de thalli circulaires ou quasi circulaires poussant sur des surfaces d'âge d'exposition connu. Les mesures ont été effectuées sur 24 surfaces historiquement datées, d'un âge compris entre 25 et 69 années, et sur trois surfaces datées au radiocarbone, comprenant ( $\mathrm{I}$ ) des digues d'écoulement boueux plus jeunes que 180 ans, (2) un mur de pierre construit par des Indiens préhistoriques environ il y a 970 ans, et (3) une moraine de fond déposée lors du retrait d'un glacier de vallée il y a environ 2460 ans datée au radiocarbone. $R$. geographicum croît très rapidement $(14 \mathrm{~mm}$ en 100 ans) pendant la première centaine d'années de sa vie. Puis la croissance se ralentit en une moyenne de $3,3 \mathrm{~mm}$ en 100 ans. La courbe complète de croissance devrait être utilisable pour dater des dépôts au plus agés de 3000 ans.

Zusammenfassung. Rezente Glazialgeschichte eines alpinen Gebietes in der Colorado Front Range, USA. I. Aufstellung einer Flechten-Wachstumskurve. Zur Datierung rezenter und periglazialer Ablagerungen im Gebiet der Indian Peaks in der Colorado Front Range wurde eine Flechten-Wachstumskurve aufgestellt. Für die Untersuchung wurde auf Grund ihrer langen Lebensspanne und ihrer zuverlässigen Beziehung zwischen Grösse und Alter die Flechte Rhizocarpon geographicum (Landkartenflechte) gewählt. Diese Gattung wächst mit verschiedener Geschwindigkeit in verschiedenen Mikrobereichen, wobei Feuchtigkeit, Festigkeit des Untergrundes und Dauer der schneefreien Jahreszeit den grössten Einfluss haben. Die Wachstumsgeschwindigkeit wurde indirekt aus der Messung der Maximaldurchmesser von kreisförmigen oder annähernd kreisförmigen Exemplaren bestimmt, die auf Oberflächen von bekannter Freilegungszeit wuchsen. Die Messungen erstreckten sich auf 24 historisch datierte Flächen im Alter zwischen 25 und 69 Jahren und auf 3 radiocarbon-datierte Flächen, nämlich (1) Schlammstromlager jünger als i8o Jahre, (2) einen Steinwall, errichtet von prähistorischen Indianern vor ungefähr 970 Jahren und (3) Grundmoräne, abgelagert von einem zurückgehenden Talgletscher vor etwa 2460 Radiocarbon-Jahren. R. geographicum wächst sehr schnell ( $14 \mathrm{~mm}$ pro 100 Jahre) während der ersten Ioo Jahre ihres Lebens. Das Wachstum verlangsamt sich dann auf einen Mittelwert von $3,3 \mathrm{~mm}$ pro ıo Jahre. Die vollständige Wachstumskurve dürfte zur Datierung von Ablagerungen mindestens bis 3000 Jahre Alter geeignet sein.

\section{INTRODUCTION}

The Front Range rises abruptly from the high plains of central Colorado to form the eastern boundary of the Colorado Rocky Mountains. Cirque glaciers east of the continental divide exist in an environment that is only marginally glacial; because the glaciers are small, they respond sensitively to minor changes in climate. Much of the Recent climatic history of the region is recorded in deposits on the floors of Front Range cirques. Because it has not yet been possible to date these deposits, we know very little about the timing and relative importance of "Little Ice Age" climatic fluctuations. This paper presents a lichen-growth curve that will make it possible, for the first time, to date the glacial sequence and to establish a Little 
Ice Age glacial chronology for the Front Range area. The growth curve was developed for the Indian Peaks region, $70 \mathrm{~km}$. north-west of Denver, Colorado (Fig. I), and is not intended to be used in other areas.

The technique of lichen-dating was pioneered by Beschel (I950, I955), who later published a comprehensive summary of the principles, methods and applications of lichenometry (Beschel, I96I). There have been many objections to the method. Some have dealt with the principles upon which lichenometry is based, and others, with examples of its misapplication.

The basic premise of lichenometry is that the diameter of the largest lichen thallus growing on a moraine, rock glacier or other surface is proportional to the length of time that the surface has been exposed to colonization and growth. This, of course, is not strictly correct. Lichen growth is highly individual, even under conditions of relatively uniform climate. Growth rates are influenced by differences in micro-environment, as well as by long-term fluctuations in regional climate. These factors, and others, influence the diameter of the largest thallus growing on a moraine or other surface. Fortunately, their effect upon dating accuracy can be minimized by an intelligent choice of species, by careful construction of the growth curve and by an awareness of the ecological problems involved in using the growth curve for dating.

Much of the opposition to lichenometry has stemmed from a few unfortunate studies in which the method has been badly abused. Where other dating methods fail, the temptation to make lichenometry "work" at all costs becomes great. In yielding to this temptation, geologists have dated glacial deposits using growth rates determined in far-distant regions and in different environments. Deposits many thousands of years old have been dated using growth rates established on surfaces exposed for only a few decades. There has also been a tendency to claim unrealistic precision for the method.

\section{Choice of Species}

Five common crustose species were considered when the present study was begun in $196 \mathrm{I}$. Umbilicaria virginis Schaer. was eliminated because of its rapid growth and short life span,

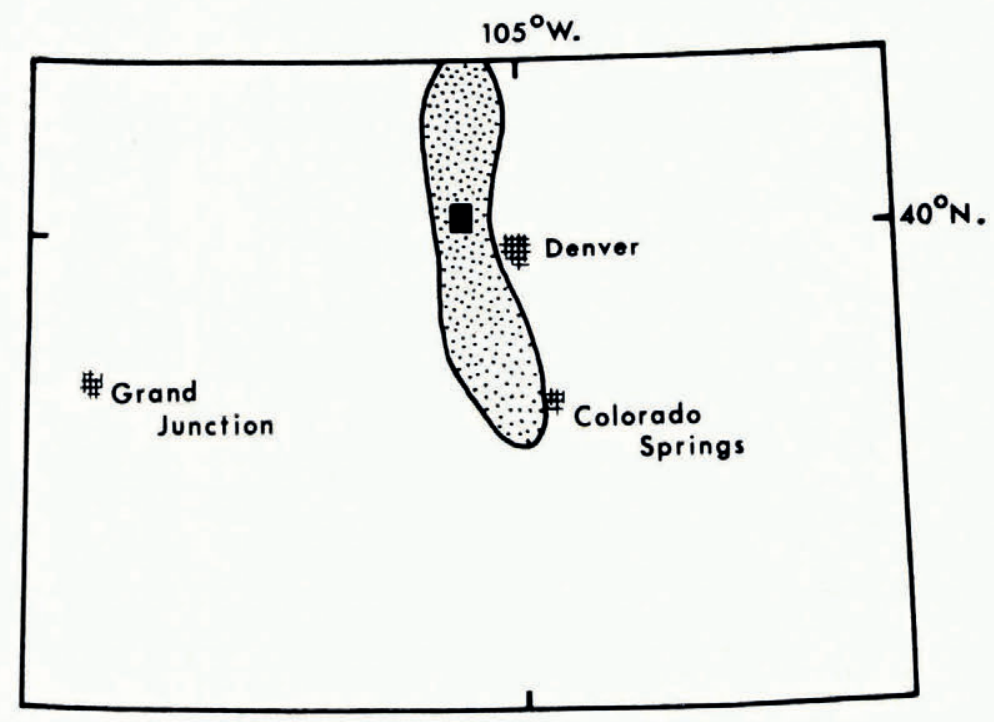

Fig. I. Outline map of Colorado, U.S.A., showing the Front Range (stippled) and the location of the Indian Peaks region (solid black) 
which make it unsuitable for dating deposits older than a few decades. Caloplaca elegans (Link) Th. Fr. was rejected because of its dependence upon calcium. Lecanora thomsonii H. Magn. and Lecidea atrobrunnea (Ram.) Schaer. were found to be satisfactory for dating surfaces younger than I, $500 \mathrm{yr}$. but they could not be used for dating older deposits. It soon became apparent that members of the genus Rhizocarpon, and particularly Rhizocarpon geographicum (L.) D.C., were the species having greatest potential for dating glacial and periglacial deposits in the Colorado Front Range.

The taxonomy of the genus is difficult and confused. Runemark (1956) has divided European representatives of the yellow Rhizocarpons into four broad groups, each of which is subdivided into a number of species and subspecies. Identification to the species level involves the examination of spores as well as the use of staining techniques, and it is complicated by the lack of a key for North American members of the genus. In order to keep the method usable on a field basis, I have dealt with the yellow Rhizocarpons in a very broad sense, without attempting to distinguish between them in the field. $R$. geographicum (L.) D.C.* is the commonest species of Rhizocarpon in the area, and it grows as rapidly, or more rapidly, than other related species. Because only the largest thallus growing on a moraine or rock glacier is normally used for dating purposes, sampling will tend to favor the selection of $R$. geographicum or of other species with similar growth rates.

Other species that occur in the area, and that were undoubtedly measured during the study, include $R$. superficiale ssp. superficiale (Schaer.) Vain. and $R$. riparium Räs. $\dagger$ Species known to be present in the area, but probably not measured, include $R$. effiguratum (Anzi) Th. Fr., $R$. sublucidum Räs and $R$. intermediellum Räs. Voucher specimens were identified by Dr. Roger Anderson, of the University of Denver, and are on file at the University of Colorado Museum Herbarium.

$R$. geographicum is abundant at high elevations in the Front Range. The wide geographic distribution of the species, together with its long life span and consistent size-age relationship, make $R$. geographicum ideal for lichenometric dating. The species grows very slowly and, in the Indian Peaks region, it can be used for dating features at least as old as 3,00o yr. Because it grows slowly, its growth curve is affected only slightly by short-term climatic fluctuations. Distinct circular thalli are common, although "complex" thalli, consisting of several individual lichens that have grown together, introduce an element of subjectivity into the dating of surfaces older than I, 00o or 2,000 yr.

\section{Ecology of R. geographicum}

Environmental factors known to affect the growth of $R$. geographicum in arctic regions and in the mountains of Scandinavia include (I) rock type, (2) exposure to abrasion, (3) shading, (4) temperature, (5) moisture, (6) stability of substrate, and (7) length of growing season. All of these factors must be understood before the species can be used for dating.

Rock type

Granite, monzonite, quartz-monzonite, quartz-biotite-gneiss, syenite and rhyolite are the most abundant rock types in the Indian Peaks region. Differences in the chemical compositions of these rocks are minor and it is not surprising that $R$. geographicum shows no definite chemical preferences. Texture generally seems to have a more important effect upon growth rates than chemistry. Coarse-textured granular rocks retain more moisture than fine-textured or glacially

* According to R. Santesson (personal communication to W. A. Weber), the original specimen of $R$. geographicum, cited by Linnaeus, is equivalent to Runemark's (1956) $R$. tinei (Tornab.) Runem. In Weber's
opinion, the name $R$. geographicum is still valid for this taxon.

$\dagger$ According to Santesson (personal communication to W. A. Weber), this is the correct name for the species treated by Runemark ( 1956$)$ as $R$. lindsayanum Räs. $R$. riparium Räs was published earlier in the same year. 
polished rocks and they are easier for $R$. geographicum to colonize. Small cracks and cavities provide protection for the young thallus. This beneficial effect may be reversed during the later stages of growth, when granular disintegration of coarse-textured rocks may destroy part or all of the lichen thallus. Moraines in the Indian Peaks region contain a variety of chemically similar but texturally diverse rock types. By sampling large areas on the moraines, the effects of textural differences can be minimized.

\section{Abrasion}

In ridge-top and summit sites above the timber line, $R$. geographicum thalli seldom reach maximum diameters on exposed west-facing surfaces. Abrasion by wind-blown ice and snow, as well as by rock particles, is probably a contributory factor (Weber, 1962). Winter wind velocities above the timber line commonly exceed $44^{\circ}-5^{\circ} \mathrm{m}$. $/ \mathrm{sec}$., and rock fragments up to I $6 \mathrm{~mm}$. in diameter have been observed in transport across the wind-slabbed snow. Paint on the windward sides of wooden stakes and weather shelters in the tundra is generally eroded away within a single winter, and the grain of the wood is deeply etched in two or three winters. For an environment of this type, the amount of obvious damage to $R$. geographicum thalli by abrasion seems surprisingly slight.

\section{Shading}

Solar radiation is intense in the alpine tundra and direct sunlight does not always seem to be essential for the growth of $R$. geographicum. The moist micro-climate of shaded northfacing rock walls is often more conducive for rapid growth than the drier micro-climate of sunny south-facing surfaces. The absence of large thalli on old moraines below the timber line, however, may be a result of shading by krummholz spruce and fir, blueberry and willow.

\section{Temperature}

Although temperature is known to have an important effect upon lichen-growth rates in other parts of the world (Beschel, I965), I have not yet been able to evaluate its importance in the Indian Peaks region. Measurements of $R$. geographicum have been made on historically dated surfaces along an altitudinal gradient extending from 3, I 25 to 4,047 m., which corresponds to a difference in mean air temperature of about $6 \cdot 6^{\circ} \mathrm{C}$. There is no evidence of a relationship between lichen growth rates and temperature along this gradient.

\section{Moisture}

The effect of moisture upon the growth of $R$. geographicum is more pronounced. Lichens can absorb moisture from water vapor in the air, from direct precipitation and from several other sources. In the Indian Peaks region, anomalously high rates of growth have been measured (I) on surfaces kept moist during the growing season by wind-blown spray from lakes, (2) around the edges of depressions that fill with water during summer rains, (3) along stream courses and seepage routes, and (4) on vertical north-facing rock walls where air humidity is high.

Very low rates of growth have been measured on south- and west-facing rock surfaces, where intense sunlight and dry westerly winds limit the amount of moisture available for lichen growth.

\section{Stability of the substrate}

Because $R$. geographicum cannot tolerate instability, ice-cored moraines and rock glaciers remain lichen-free until their covering of rock debris has thickened to the point that at least a few stones no longer shift and topple. Colonization by R. geographicum begins in two types of 
sites: ( I) on very large boulders firmly anchored in the ice core and overlying debris, and (2) on very small stones grown together by mosses in relatively stable areas.

I do not know how long a thallus can survive when the rock on which it grows is overturned and the lichen is deprived of direct sunlight. Experiments suggest that $R$. geographicum can survive for at least $5 \mathrm{yr}$. on stones that have been overturned in rocky areas, but that thalli are destroyed by a similar period of burial in contact with moist soil.

\section{Length of snow-free growing season}

Lichen-growth rates are strongly influenced by the length of the growing season. In alpine tundra regions, the growing season is always brief and it varies within short distances as a result of differences in snow cover. In the Sierra Nevada of California, a snow-free period of at least 4-6 weeks per summer seems to be necessary for lichen survival (personal communication from Robert R. Curry). The length of the snow-free period needed for lichen survival in the Front Range is unknown; observations are complicated by the fact that an area snowfree for ro weeks one summer may remain snow-covered throughout all of the succeeding summer. It is difficult to judge whether the lichen-free zones that encircle perennial snow banks are a result of present snow-accumulation conditions, or date from earlier periods of expanded snow cover, or are simply the result of disturbance by freeze-thaw processes.

The effects of late-lying snow upon lichen-growth rates have not been a serious problem in the present study. The transverse ridges of rock glaciers and the crests of almost all moraines in the Front Range remain essentially free of snow throughout the winter. All points on the lichen-growth curve have been based upon measurements made in similar sites.

\section{Choice of Methods}

In order to date with lichens, it is necessary to learn how rapidly they grow. Growth rates can be determined either directly, by measuring the growth of individual lichen thalli over a period of many years (Hausman, I948; Hale, 1959; Beschel, 1963), or indirectly, by measuring the diameters of the largest lichens growing on surfaces of known age (Platt and Amsler, I955; Beschel, I958[a], [b]; Stork, I963; Andrews and Webber, r964; Reger, unpublished). Attempts to determine the minimum ages of living thalli by radiocarbon dating have not been successful (Eilif Dahl, in Nydal and others, 1964). As suggested in the following paragraphs, many of the problems otherwise involved in dating with lichens can be avoided if the growth curve is established indirectly.

(I) Lichens grow very slowly and only the slowest-growing species, such as $R$. geographicum, are useful for dating surfaces older than a few centuries. Because 5 , io and even $20 \mathrm{yr}$. may be required before thalli of these species have grown a measurable amount, it is generally impractical to measure the growth rates of individual plants. By measuring the largest thalli growing on dated surfaces, a growth curve can be established in a single field season.

(2) Crustose lichens do not grow at a constant rate throughout their lives. Beschel ( $95^{8}$ [a]) has shown that many species begin to grow very slowly, then accelerate and eventually slow to a constant rate that may continue for several thousand years before senescence is reached. If growth-rate studies are to be based upon the annual diameter increase of individual lichens, a large number of thalli, both large and small, must be measured. Changes in growth rate that occur as a lichen matures will be automatically reflected in the growth curve determined by indirect methods.

(3) Thalli of the same species and size, growing in what appear to be identical environments, often grow at different rates. Growth may be intermittent, occurring only in favorable years. One part of a thallus may increase in size, while other parts show 
no appreciable change. These factors combine to make the construction of growth curves by direct methods difficult and unreliable. If growth rates are determined indirectly, the effects of short-term fluctuations in climate are minimized and intervals of erratic or intermittent growth are averaged out.

(4) Lichen-growth rates are also influenced by long-term changes in regional climate. Because important changes in climate have occurred frequently during the life spans of most large lichen thalli, growth rates based upon the behavior of a few individual thalli during a relatively short period of years should not be extrapolated very far backward into the uncertain past. This problem also can be avoided by indirect measurement; the effects of long-term climatic fluctuations are automatically included in the growth curve determined indirectly.

(5) Direct methods give no information about the length of time required for lichens to colonize a newly exposed rock surface. Bare surfaces can be cleared and photographed, but few species will re-colonize during a practical length of time. The time required for colonization must generally be determined by indirect methods.

Unfortunately, a choice of methods is not always offered. Dated surfaces are rare in the areas where lichenometry is most urgently needed. This is true for the Indian Peaks region, where dated surfaces older than $70 \mathrm{yr}$. are practically non-existent. In beginning the present study, I felt that the advantages of indirect measurement were compelling enough to justify a search for older surfaces that might lend themselves to radiocarbon dating. The remainder of this paper is devoted to dated surfaces of historic age and older, and to the lichens that have colonized them.

\section{Historically Dated Surfaces}

Twenty-four historically dated surfaces were located within the Indian Peaks region. The maximum diameters of circular or nearly circular $R$. geographicum thalli growing on these surfaces were measured during the summer of 1966 , and the results are listed in Table I. Most of the data are self-explanatory but several of the sites require further discussion.

All of the cairns (Fig. 2) were constructed in I910, using stones gathered locally. A trimline on each stone makes it possible to tell which parts were initially buried and which were initially exposed and lichen-covered. Lichens were measured only on surfaces that were definitely bare when the cairns were built. $R$. geographicum thalli are absent on seven of the 13 cairns and in all cases they are very small, reaching maximum diameters of only $2 \mathrm{~mm}$. Because the cairns are located on exposed windswept summits, the lichens receive moisture only from direct precipitation and condensation. Evaporation rates are high and abrasion by blowing snow further inhibits lichen growth. At elevations above $3,600 \mathrm{~m}$., R. geographicum is restricted to the lee east-facing sides of cairns; at lower elevations, the species shows a preference for shaded north- and north-east-facing surfaces.

Two of the surfaces listed in Table I are unusually moist. At Green Lake No. 5, lichens were measured below a prominent trimline that marks the level of the lake prior to I 909 , when the outlet stream was deepened. $R$. geographicum thalli $12 \mathrm{~mm}$. in maximum diameter grow on rock surfaces below the trimline. Wind-blown spray keeps these thalli saturated throughout the growing season and lichen growth is unusually rapid. Very rapid growth was also noted in the quarry south of Silver Lake. The quarry was excavated during the winter of I 1 I I-I 2. By $1966, R$. geographicum thalli had reached maximum diameters of $14 \mathrm{~mm}$. on the vertical, west- and north-west-facing quarry walls, which are shaded almost continually. Air humidity is high and seepage down the rock face provides the lichens with additional moisture. Both of these sites are exceptionally moist; this type of environment is not generally duplicated on moraines or rock glaciers and the lichen measurements from Silver Lake and Green Lake No. 5 have not been included in the final growth curve. 
RECENT GLACIAL HISTORY OF THE COLORADO FRONT RANGE. I

Table I. Maximum Diameters of $R$. geographicum Thalli Growing on Historically Dated Surfaces in the Indian Peaks Region. Measurements from Two Unusually Moist Sites are Starred and have not been Used in Constructing the Growth Curve

\begin{tabular}{|c|c|c|c|c|c|}
\hline Location & Type of surface & $\begin{array}{l}\text { Elevation } \\
\mathrm{m} .\end{array}$ & Exposure & Age & $\begin{array}{l}\text { Diameter } \\
\mathrm{mm} \text {. }\end{array}$ \\
\hline Green Lake No. 3 & $\begin{array}{l}\text { Riprap facing on rock-fill } \\
\text { dam }\end{array}$ & $3,45^{\circ}$ & South-east & I $94^{\mathrm{I}}$ & Absent \\
\hline Green Lake No. I & $\begin{array}{l}\text { Riprap facing on rock-fill } \\
\text { dam }\end{array}$ & $3,43^{\circ}$ & North-west & c. $194^{\circ}$ & 4 \\
\hline Green Lake No. 2 & Quarry north of dam & $3,4^{1} 5$ & South-west & $193^{8}$ & Absent \\
\hline Triple Lakes & $\begin{array}{l}\text { Rock fill behind concrete } \\
\text { wall of flume at gauging } \\
\text { station }\end{array}$ & 3,220 & Horizontal & 1933 & 5 \\
\hline Green Lake No. 3 & $\begin{array}{l}\text { Tailings below tunnel } \\
\text { entrance }\end{array}$ & $3,5^{25}$ & South & c. 1928 & Absent \\
\hline Lefthand Reservoir & Floor of drained lake & 3,235 & Horizontal & 1919 & 6 \\
\hline Lake Albion & Bedrock cut below dam & 3,340 & North-west & c. 1913 & 6 \\
\hline Silver Lake & Quarry south of outlet & 3,125 & West & 1912 & $14^{*}$ \\
\hline Kiowa Peak & Summit cairn & 4,047 & - & 1910 & Absent \\
\hline Arikaree Peak & Summit cairn & 4,008 & East & 1910 & 2 \\
\hline Navajo Peak & Cairn & 3,914 & - & 1910 & Absent \\
\hline Mount Albion & Summit cairn & 3,843 & - & 1910 & Absent \\
\hline East end of "Baldy" & Cairn & $3,75^{2}$ & East & 1910 & I \\
\hline Niwot Ridge & Cairn & 3,744 & 一 & 1910 & Absent \\
\hline Albion Saddle & Cairn & 3,731 & - & 1910 & Absent \\
\hline Albion Saddle & Cairn & 3,718 & - & 1910 & Absent \\
\hline Niwot Ridge & Cairn & 3.621 & North-north-east & 1910 & 2 \\
\hline Albion Ridge & Cairn & $3,4^{22}$ & North & I9Io & I \\
\hline Elk's Roost & Cairn & 3,404 & North & I910 & 2 \\
\hline Lake Albion & Cairn & $3,39^{1}$ & North-east & 1910 & $2^{2}$ \\
\hline Albion town site & Cairn & 3,312 & - & 1910 & Absent \\
\hline Green Lake No. 5 & $\begin{array}{l}\text { Shore of lake, below old } \\
\text { trimline }\end{array}$ & 3,615 & Horizontal & 1909 & $12^{*}$ \\
\hline $\begin{array}{l}\text { Goose Lake } \\
\text { Island Lake }\end{array}$ & Quarry north of outlet & 3,220 & North-west & I908 & 5 \\
\hline Island Lake & Quarry east of dam & 3,140 & North & c. 1897 & 9 \\
\hline
\end{tabular}

\section{Radiogarbon-Dated Surfaces}

No historically dated surfaces older than $69 \mathrm{yr}$. have been located in the Indian Peaks region. In order to extend the growth curve backward in time, three older surfaces were radiocarbon dated. These surfaces included (I) mudflow levees east of Arapaho Glacier, (2) a stone wall built by prehistoric Indians on Albion Ridge, and (3) ground moraine in the upper Silver Lake valley. Because each point on the lichen-growth curve has involved a different approach, each is discussed separately and in detail.

\section{Mudflow levees}

Intense summer thunderstorms often trigger mud and debris flows in the high glacial valleys of the Indian Peaks region. The flows begin in couloirs on the valley walls and terminate on late-lying snow banks, on talus or on the vegetation-covered valley floor. In their upper parts the flows erode deep trenches into the talus, but on lower slopes they cause no erosion, and instead deposit prominent mudflow levees (Sharp, I942; Curry, I966).

Lichens seldom survive this type of transport. Of ten fresh mudflow deposits examined in the area since 1963 , only two included an occasional lichen-covered boulder. Because of the instability of the fresh levees, particularly those that terminate on snow, it is unlikely that even these thalli will remain alive 5-ro yr. after the date of the flow.

In trenching recent mudflow levees I have generally found that the plant cover buried beneath them remains intact. Leaves may be torn away but stems are rooted and undisturbed. The A horizon is unbroken. As a result, where mudflows terminate on the vegetated valley floor, a buried A horizon is preserved that makes it possible to date the flows by radiocarbon analysis. 
A pair of mudflow levees on the south wall of the upper Silver Lake valley, $\mathrm{I} \cdot 4 \mathrm{~km}$. east of Arapaho Glacier, was chosen for radiocarbon dating and lichen measurement (Fig. 3). The lower part of the flow lies at an elevation of about $3,500 \mathrm{~m}$., where it extends across a lush alpine meadow. The levees are composed of cobbles and boulders set in a matrix of silt and sand. Sorting is poor. Precambrian biotite-gneiss, granite-porphyry and migmatite are the dominant rock types, with an occasional boulder of pegmatite or aplite.

A trench dug across the westernmost levee exposed a buried A horizon, $5-7 \mathrm{~cm}$. thick, beneath a maximum thickness of $85 \mathrm{~cm}$. of unsorted mudflow material (Fig. 4). Outside the levee, $2 \cdot 8 \mathrm{~m}$. west of its crest, the buried A horizon merged with the modern turf.

${ }^{14} \mathrm{C}$ dating of buried soils is problematical (Benedict, I 966). The sampling method used in this study was designed to eliminate the problem of correcting for the unknown radiocarbon age of the A horizon at the time of burial. The upper part of the levee was cleared away, until about I $\mathrm{m}^{2}$ of the surface of the buried humus layer was exposed to view. The surface was then carefully scraped, so that only the top I mm., representing the remains of vegetation actually living on the ground surface at the time of the flow, was removed. No correction is believed necessary for the date of $<\mathrm{r} 80 \mathrm{yr}$. B.P. determined by Isotopes Inc. for this sample (I-2425).

In order to be certain that no lichens had survived the mudflow, I measured the diameters of $\mathrm{I}, 500 \mathrm{R}$. geographicum thalli growing on the crests and sides of the levees. Because the sizefrequency distribution is continuous and unimodal (Fig. 5), I believe that the levees were entirely lichen-free after their deposition, and that all thalli now growing at the site are younger than $\mathrm{i} 80$ radiocarbon years. $R$. geographicum has grown to a maximum diameter of I $7 \mathrm{~mm}$. during this period.

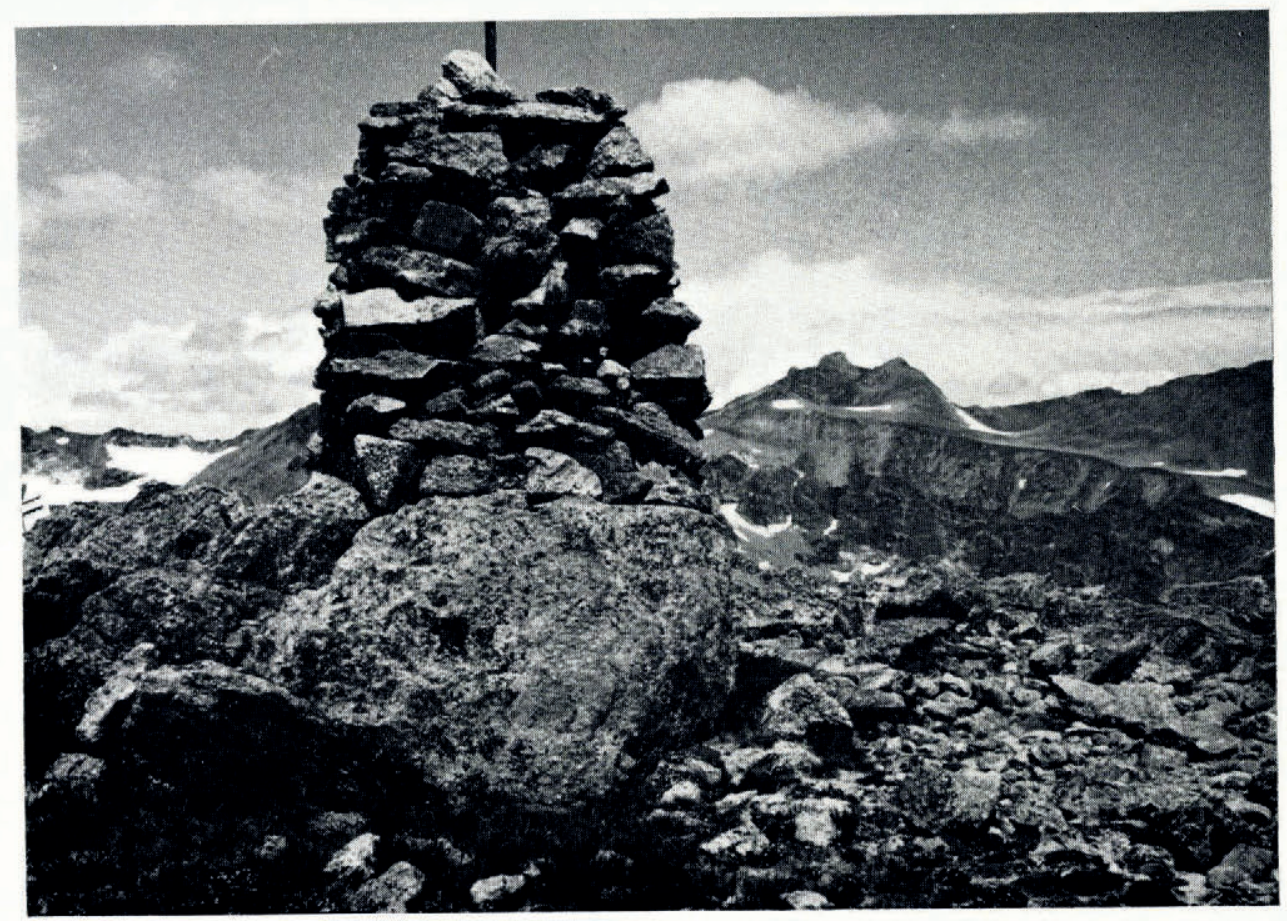

Fig. 2. City of Boulder Triangulation Monument No. I3, east end of "Baldy". Many fresh rock surfaces were exposed when the cairn was built in 1910 . Lichens have been slow to colonize these surfaces because of the exposed and windy environment (27 July 1966) 


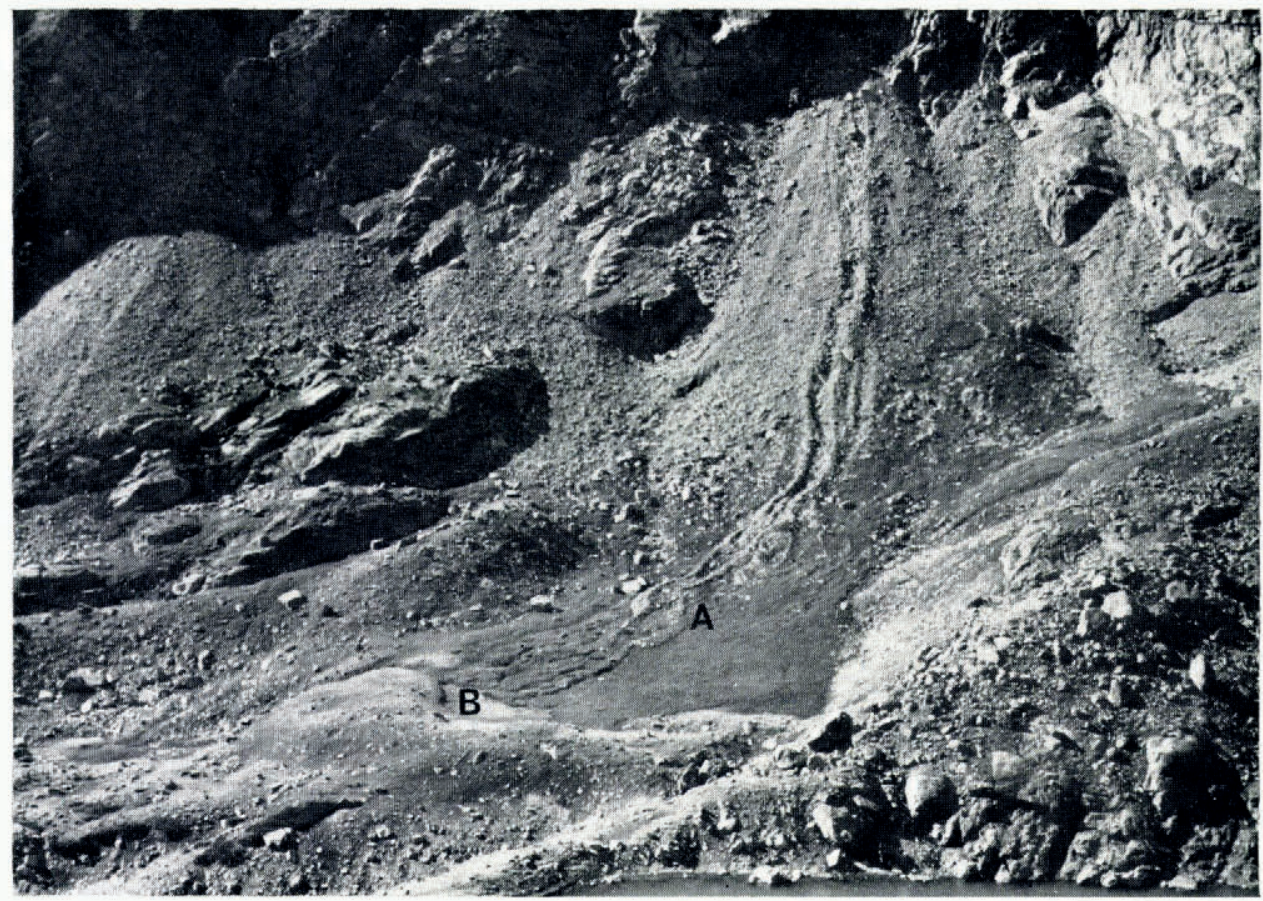

Fig. 3. View of the south wall of the upper Silver Lake valley, showing the locations of ${ }^{4}{ }_{4} C$ samples used in establishing a growth curve for R. geographicum. A sample of buried A-horizon material collected from beneath the mudflow levee at $A$ was dated at $<180 \mathrm{yr}$. B.P. Radiocarbon dates from the dry lake basin at B suggest that drainage from the glacier front was diverted away from this side of the valley approximately 2,46o yr. ago (Io August 1966 )

E

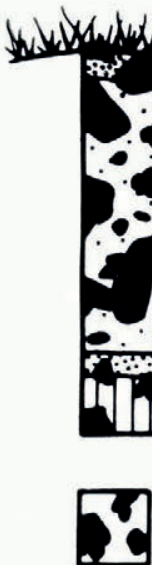

1

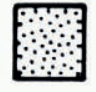

2

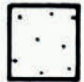

3

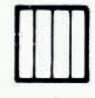

4
W

bil

Fig. 4. Cross-section of a mudflow levee, $1 \cdot 4 \mathrm{~km}$. east of Arapaho Glacier. A radiocarbon sample was collected from the top I $\mathrm{mm}$. of the buried A horizon, just west of the crest of the levee

I. Cobbles and boulders. 2. Very dark brown loamy sand A horizon. Rich in organic matter. 3. Poorly sorted mudflow debris. Stones and gravel in a matrix of olive-gray loamy sand. 4. Dark yellowish brown gravelly loamy sand $C$ horizon 


\section{Indian wall}

During the past 4,00o yr., the Indian Peaks region has frequently been visited by prehistoric Indians, who camped in the wooded valleys, hunted deer and mountain sheep in the timber-line region, and gathered roots and berries on the high rolling uplands along the continental divide. Complexes of low rock walls and shallow rock-walled pits, similar to the caribou "drives" of Alaska, Greenland and arctic Canada, occur on many alpine ridge tops. in the area. An important group of walls and pits, from which a short series of projectile points has been obtained (paper in preparation by Benedict, Murray and Murray), lies $700 \mathrm{~m}$. north-east of the summit of Mount Albion. The elevation of the site is $3,660 \mathrm{~m}$. A radiocarbon date on charcoal from one of the pits suggests that the structures were built $970 \pm \mathrm{I}$ oo yr. ago (M-I542), or in approximately A.D. 980 .

From its junction with the main group of pits, a prominent stone wall, $60-90 \mathrm{~cm}$. high, extends south-westward for a distance of 1 io m. (Fig. 6). For much of this distance the wall is built across the surface of a group of sorted nets, a type of frost-patterned ground transitional between sorted polygons and stripes (Washburn, I956). Soil-profile development suggests that the centers of the sorted nets have been inactive for at least several thousand years.

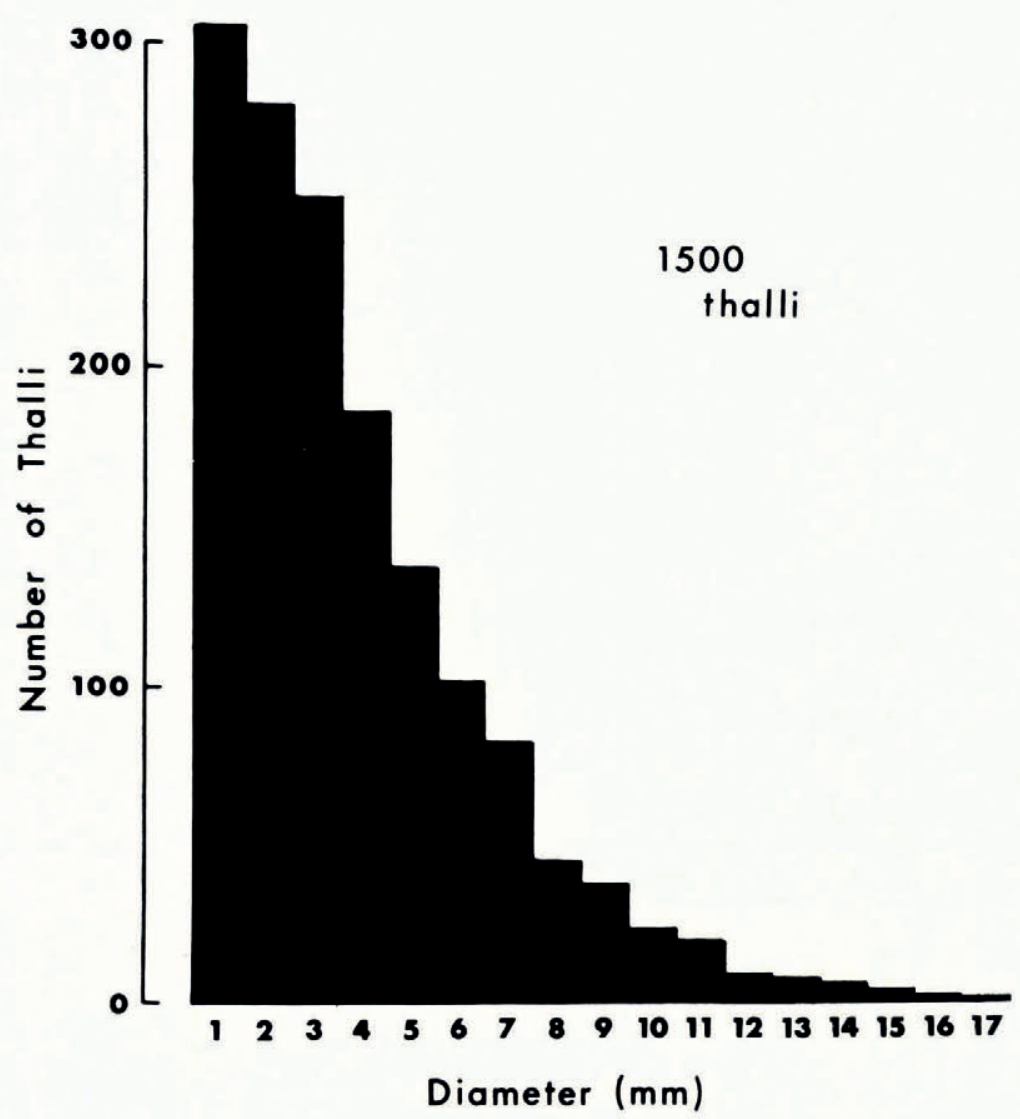

Fig. 5. Size-frequency histogram for $R$. geographicum thalli growing on mudflow levees $\mathrm{I}_{4} 4 \mathrm{~km}$. east of Arapaho Glacier. The largest thallus has a diameter of $17 \mathrm{~mm}$. The population distribution implies continuous reproduction, and none of the thalli appear to have been survivors of the mudflow 
The Indian wall was built with cobbles and small boulders of quartz-biotite-gneiss gathered from the borders of the sorted nets. Although many lichens were able to continue growing in their new locations on the wall, others were destroyed, and many bare rock surfaces must have been exposed. Unlike the r 9 io cairns, however, trimlines are no longer visible. During the summer of $1965, \mathrm{Mr}$. K. L. Petersen assisted me in a program of lichen sampling at the Mount Albion site. We hoped that the sudden exposure of many fresh rock surfaces $970 \mathrm{yr}$. ago would be reflected in the size structure of the lichen community growing on the wall today. By comparing this community with the undisturbed community growing on the nearby sorted nets, we planned to determine the maximum diameters of $R$. geographicum thalli that have colonized bare rock surfaces exposed in building the wall.

Twenty sampling localities were chosen at regular intervals along the Indian wall. Ten additional stations were selected in the borders of nearby sorted nets, with care taken (I) to select areas in which the micro-environment was similar to that of the wall, and (2) to avoid areas from which rocks might have been removed by Indians in building the wall.

The maximum diameters of all $R$. geographicum thalli larger than io $\mathrm{mm}$. were measured, until a total of $\mathrm{I}$ oo had been recorded at each sampling locality. In this manner, 2,00o lichens were measured on the wall and $\mathrm{I}, \mathrm{OoO}$ in the adjacent sorted nets. In order to cancel out the effects of possible differences in measurement technique, each observer measured lichens at half of the wall stations and at half of the sorted-net stations. The data were analyzed in two different ways, each of which gave slightly different results.

Rank correlation. The measurements were combined into $5-\mathrm{mm}$. diameter classes and each class was ranked according to the percentage of the total sample that fell within it. The diameter class containing the largest number of thalli was assigned the rank of $\mathrm{I}$; the class having the smallest number was assigned the rank of 18 . The data are graphed in Figure 7.

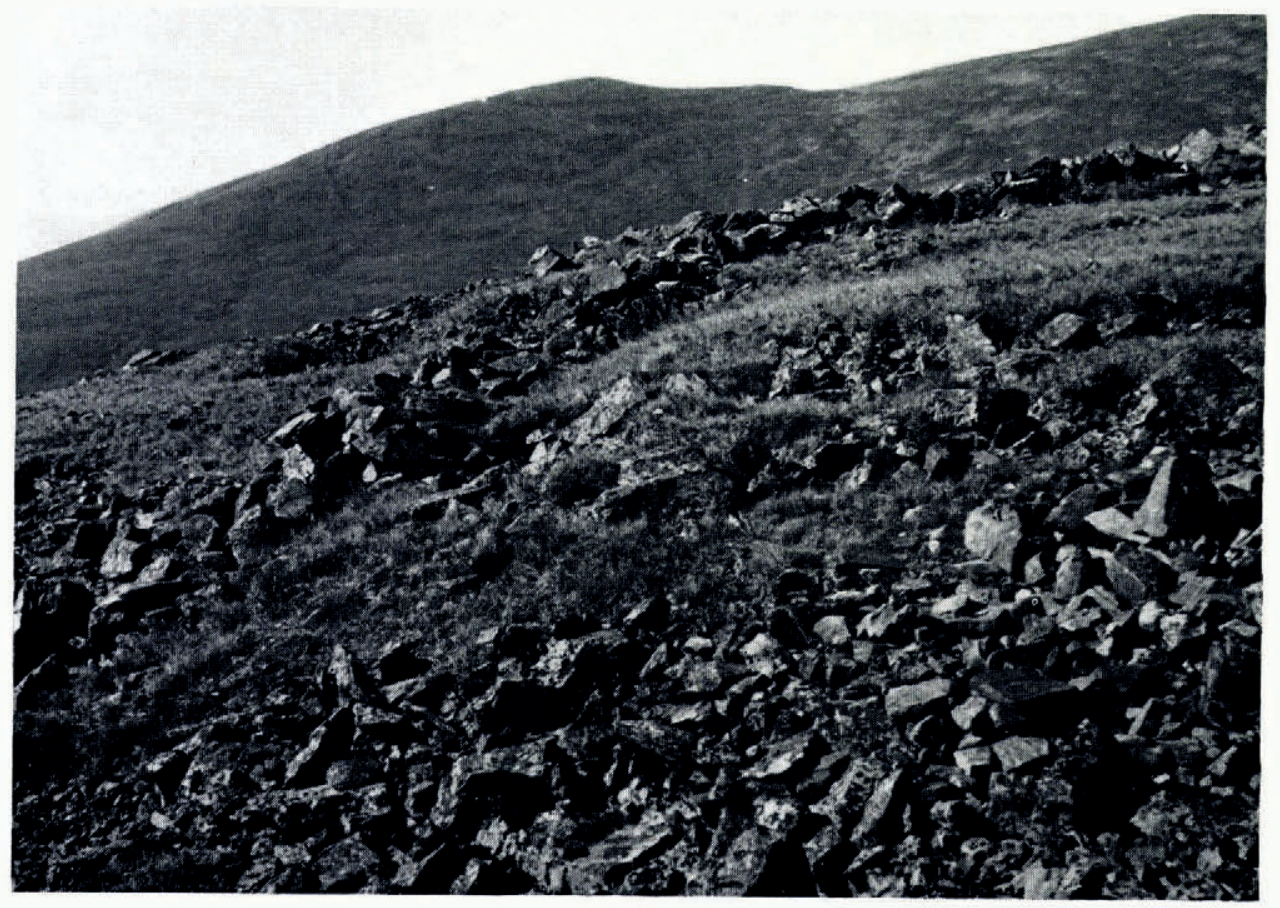

Fig. 6. Indian wall at the Mount Albion site. The wall is sinuous and crosses a group of sorted nets and polygons. Charcoal from a pit associated with this wall has been radiocarbon dated at $970 \pm 100$ yr. B.P. $(M-1542)(18$ August 1966$)$ 


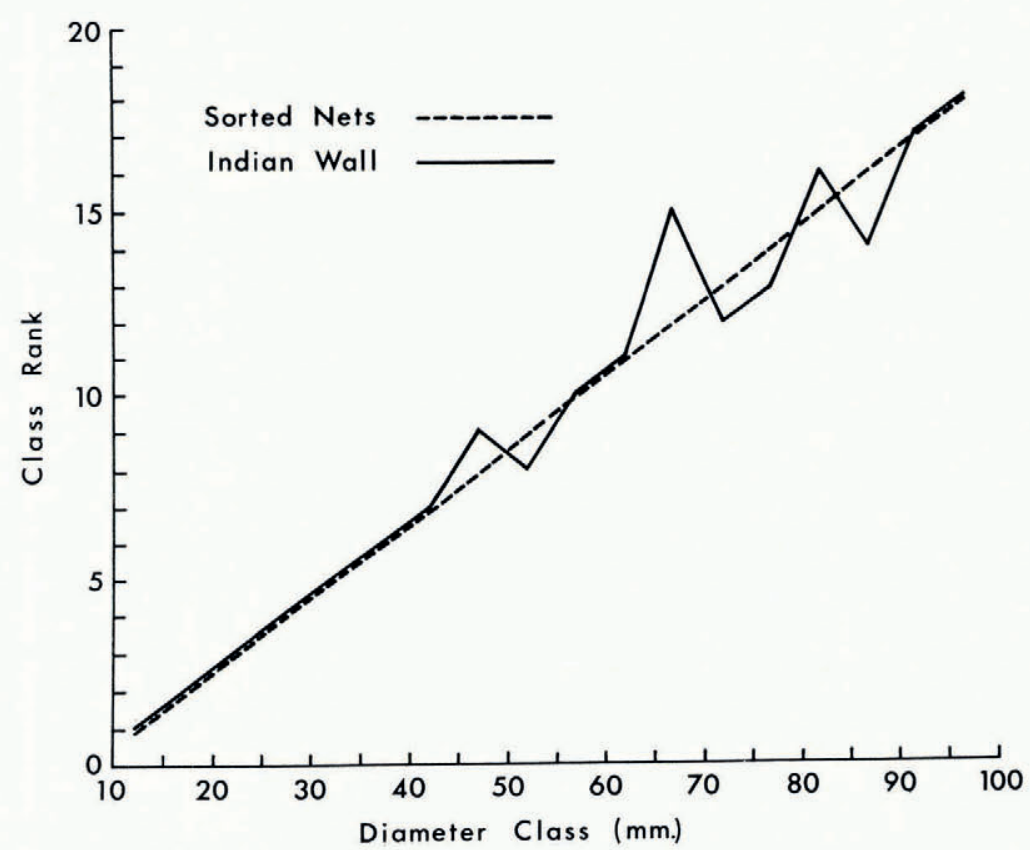

Fig. 7. Comparison of two communities of $R$. geographicum at the Mount Albion site. Lichen measurements were grouped into $5 \mathrm{~mm}$. diameter classes and each class was ranked according to the percentage of the total sample that it contained. The largest class was given the rank of 1 , and the smallest the rank of 18 (see text). Comparison of the two curves suggests that $R$. geographicum thalli have grown to maximum diameters of $45-49 \mathrm{~mm}$. since the Indian wall was built

For lichens growing in the sorted nets, the number of thalli present in each diameter class decreased uniformly as the thalli became larger. This is illustrated by the straight dashed line in Figure 7. For the Indian wall, a similar relationship existed among the smaller thalli; the relationship began to disintegrate in the $45-49 \mathrm{~mm}$. diameter class, however, and it was erratic for all larger thalli.

The data suggest (I) that the lichen community growing in the borders of the sorted nets has not been seriously disturbed since its establishment; (2) that thalli larger than $45^{-49} \mathrm{~mm}$. on the Indian wall represent the remnants of a lichen community disturbed by construction of the wall; and (3) that thalli smaller than $45^{-49} \mathrm{~mm}$. have become established since the wall was built. The mid-point of the $45^{-49} \mathrm{~mm}$. diameter class is equated with a surface exposed in approximately A.D. 980.

Size-frequency analysis. The data were combined into Io-mm. diameter classes and sizefrequency curves were constructed. A marked difference between the two communities became apparent when frequency was plotted on a logarithmic scale (Fig. 8).

For lichens growing in the borders of the sorted nets, a straight-line relationship between diameter and the logarithm of frequency suggests that disturbance has been absent. No single straight line can be fitted to the data for the Indian wall; instead, two intersecting lines are required (Fig. 8). The gently sloping solid line is believed to apply to the survivors of wall building; its position shows that approximately 70 per cent of the original lichen cover was destroyed in building the wall. The steeply sloping solid line is believed to represent the lichen community that has become established on surfaces exposed during construction of the wall. The intersection of the two solid lines marks the maximum diameter attained by $R$. geographicum since the wall was built; according to this interpretation, thalli at the site have grown to maximum diameters of $40 \mathrm{~mm}$. since about A.D. 980 . 


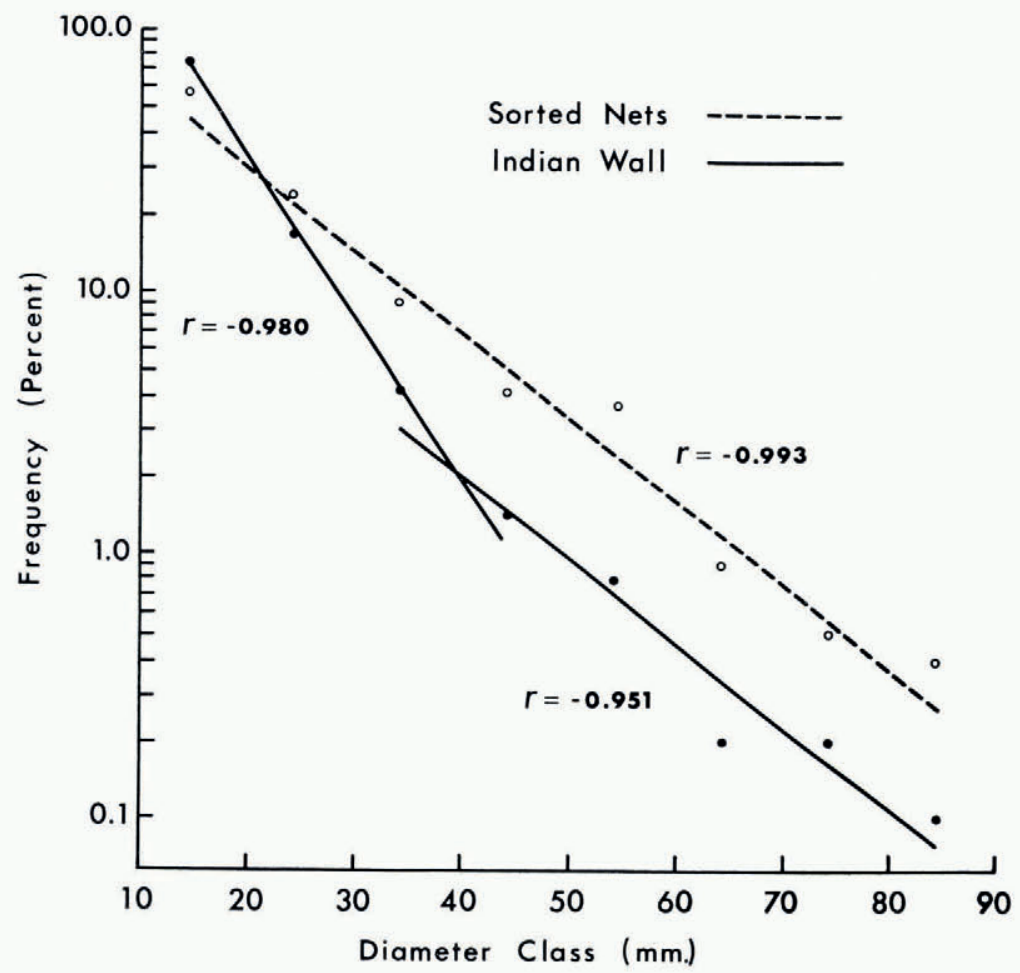

Fig. 8. Size-frequency curves for two populations of R. geographicum at the Mount Albion site. Regression lines were fitted to the data using the method of least squares and correlation coefficients were computed. Lichens larger than $40 \mathrm{~mm}$. on the Indian wall are survivors of wall building. These thalli began their growth in the borders of sorted nets and were able to continue growing when the rocks on which they had become established were moved to positions on the wall. Thalli smaller than $40 \mathrm{~mm}$. have colonized bare rock surfaces exposed during construction of the wall, approximately 970 radiocarbon years ago

\section{Ground moraine}

During a late phase of the earliest Little Ice Age glaciation recognized in the Indian Peaks region, ice from the Arapaho Cirque advanced $\mathrm{I} \cdot 4 \mathrm{~km}$. down the Silver Lake valley. Near the terminus of the glacier, a bedrock ridge divided the flow of ice into two lobes, each of which deposited a small terminal moraine. During the early stages of stagnation and retreat, melt water from the glacier front was impounded behind each of the two ice-cored moraines. As the southern lobe of the glacier receded up-valley, however, its drainage shifted to the north, and the southern lake was cut off from its source of glacial melt water. The change in drainage occurred when the ice front stood $0.5 \mathrm{~km}$. behind its terminal position.

At present, the basin contains standing water only during the spring and early summer, becoming dry as soon as snow banks on the south valley wall have melted away. The floor of the old lake bed is partially bare, partially covered by sedge meadow and partially overgrown by willows (Fig. 3).

A pit dug into the floor of the pond revealed a thick sequence of proglacial lake sediments, overlain by a poorly sorted colluvial layer rich in organic matter. This, in turn, was buried beneath I I $\mathrm{cm}$. of sandy debris derived from the mudflow deposits that encroach upon the lake floor at its southern end.

A sample collected from the base of the colluvium, at a depth of $39-4 \mathrm{I} \mathrm{cm}$., was dated at $4 \mathrm{IO} \pm \mathrm{I} 20 \mathrm{yr}$. B.c. (I-2424) and $6 \mathrm{IO} \pm \mathrm{I} 00 \mathrm{yr}$. B.C. (I-2469). These radiocarbon ages apply to 
the boundary between lake sedimentation and colluvial deposition, and they date the shift in melt-water drainage that occurred when the front of the glacier had retreated $0.5 \mathrm{~km}$. up-valley from the moraine.

Lichens were measured on boulders in the area occupied by the retreating ice front when drainage suddenly shifted to the north and the lake became dry. The largest $R$. geographicum thallus growing at this location has a diameter of $94 \mathrm{~mm}$. This thallus is believed to have colonized the ground moraine approximately 2,460 radiocarbon years ago, or in about 5 IO B.C.

\section{Conclusions}

A completed growth curve for $R$. geographicum is shown in Figure 9. The curve is based upon (A) the largest thalli measured on historically dated surfaces in the area, excluding two sites that were unusually moist; (B) the largest thallus growing on mudflow levees radiocarbondated as being younger than $\mathrm{r} 80 \mathrm{yr}$; (C) the maximum diameters of $R$. geographicum thalli growing on 970-yr. old rock surfaces exposed by Indians at the Mount Albion site, and (D) the largest thallus growing on ground moraine in an area deglaciated about 2,460 radiocarbon years ago.

After an initial roo-yr. period of rapid growth (I $4 \mathrm{~mm}$./ I0o yr.), R. geographicum grows slowly and steadily, with an average diameter increase of $3.3 \mathrm{~mm}$./ Ioo yr., for many thousands of years. This value is very low by world-wide standards, and it is matched in its slowness

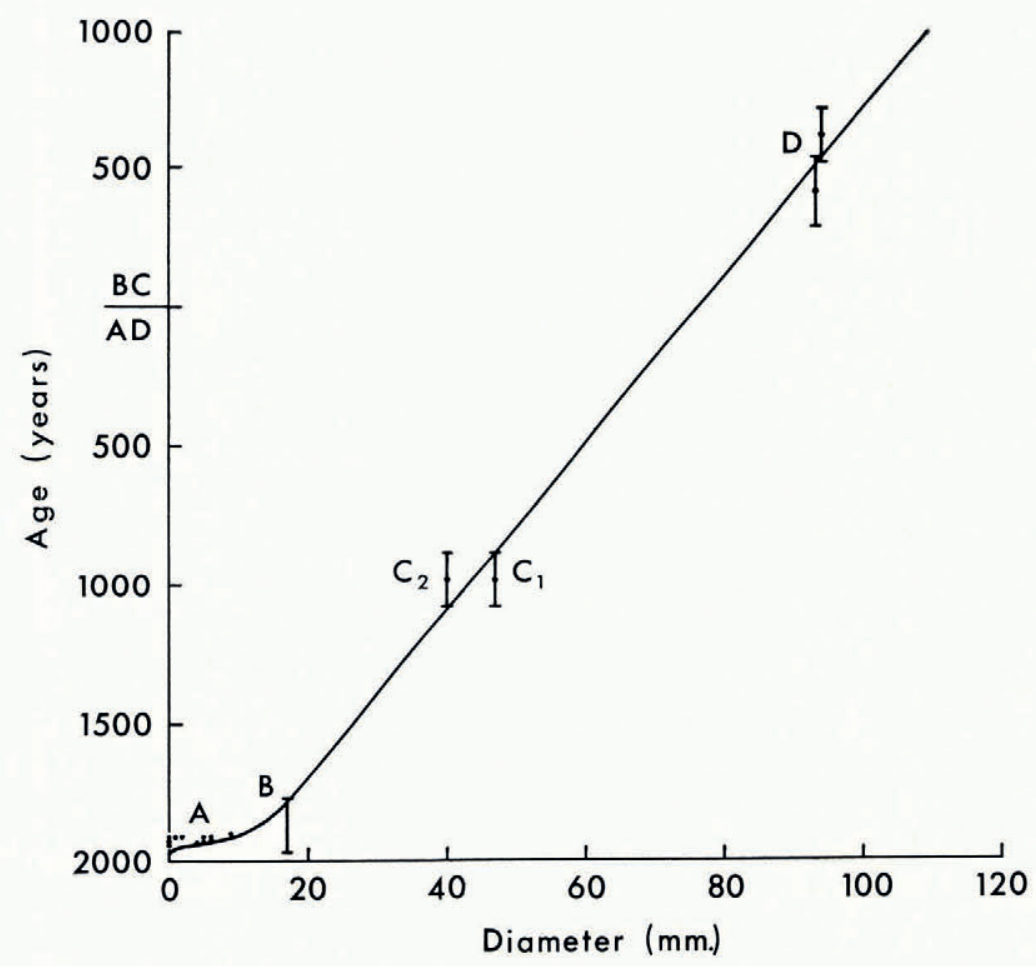

Fig. 9. Growth curve for R. geographicum in the Indian Peaks region, Colorado Front Range. Lichen diameters were measured on $(A) 24$ historically dated surfaces, $(B)$ mudflow levees, $(C)$ an Indian wall, and $(D)$ ground moraine deposited at the close of the earliest Little Ice Age glacial advance in the region. In order to use the Indian wall as a dated surface, lichen population data from the wall and from adjacent sorted nets were compared by rank correlation $\left(C_{\mathrm{I}}\right)$ and size-frequency analysis $\left(C_{2}\right)$. Vertical lines show the statistical errors of radiocarbon dates 
only by growth rates measured in the interior of West Greenland (Beschel, I96r). Slow growth in the Indian Peaks region is probably a result of deficient moisture.

Changes in growth rate caused by long-term variations in climate are not apparent in the growth curve. As additional dated surfaces become available, it may become possible to refine the curve and to use temporal variations in lichen-growth rates as a measure of long-term moisture trends.

The growth curve is intended to be used only for dating surfaces younger than $3,000 \mathrm{yr}$. It is tempting, nevertheless, to assume a constant rate of growth on older surfaces in order to estimate the ages of the oldest living lichens in the Front Range area. The largest $R$. geographicum thallus measured in the Indian Peaks region has a diameter of $220 \mathrm{~mm}$., and it must be very close to $6,000 \mathrm{yr}$. old. This compares with an age of approximately $4,900 \mathrm{yr}$. for the oldest known living bristlecone pine (Currey, r965).

The growth curve was developed solely for use in the Indian Peaks region. Many surfaces in this part of the Front Range cannot be dated with lichens, and there are many microenvironments in which growth rates will differ significantly from those shown in Figure 9. With knowledge of the ecology of the species, problem areas can be avoided. Because of the nature of the surfaces on which the growth curve was derived, its use should be restricted to granitic rock types in sites that become snow-free by late spring or early summer. Extremely moist sites should be avoided.

\section{Acknowledgements}

I am grateful to Mr. Kenneth L. Petersen for his assistance in the field during the summer of I $_{96}{ }_{5}$, and to Mrs. Diane G. Benedict for her help in searching local newspaper files and City Council records to find the ages of historic surfaces in the Boulder Watershed. To the city of Boulder, Colorado, and particularly to Mr. Bill Light and Mr. Tom Platt, I should like to express my thanks for permission to work in an area normally closed to the public. The University of Michigan generously dated a charcoal sample from the Mount Albion site, and a grant from the Society of the Sigma Xi and R.E.S.A. Research Fund paid for two additional radiocarbon dates. Mr. Samuel I. Outcalt suggested the use of a graphic rank-correlation technique for comparing lichen populations at the Mount Albion site. Dr. Roger Anderson identified voucher specimens of the lichens used in the study and discussed many of the problems involved in their taxonomy. I am particularly grateful to Mr. Robert R. Curry and to Dr. William A. Weber for their comments on the manuscript.

\section{MS. received 30 December 1966}

\section{REFERENCES}

Andrews, J. T., and Webber, P. J. I964. A lichenometrical study of the northwestern margin of the Barnes Ice Cap: a geomorphological technique. Geographical Bulletin (Ottawa), No. 22, p. 80-104.

Benedict, J. B. 1966. Radiocarbon dates from a stone-banked terrace in the Colorado Rocky Mountains, U.S.A. Geografiska Annaler, Vol. 48A, No. 1, p. 24-31.

Beschel, R. E. I950. Flechten als Altersmassstab rezenter Moränen. Zeitschrift für Gletscherkunde und Glazialgeologie, Bd. 1 , Ht. 2, p. $152-61$.

Beschel, R. E. 1955. Individuum und Alter bei Flechten. Phyton: Annales Rei Botanicae (Horn), Vol. 6, Nos. I-2, p. $60-68$.

Beschel, R. E. 1958[a]. Flechtenvereine der Städte, Stadtflechten, und ihr Wachstum. Berichte des Naturwissenschaftlich-medizinischen Vereins in Innsbruck, Bd. $5^{2}$.

Beschel, R. E. 1958[b]. Lichenometrical studies in West Greenland. Arctic, Vol. I 1, No. 4, p. 254.

Beschel, R. E. 1961. Dating rock surfaces by lichen growth and its application to glaciology and physiography (lichenometry). (In Raasch, G. O., ed. Geology of the Arctic: proceedings of the first international symposium on Arctic geology held in Calgary, Alberta, January $I_{1-13}, 1960$. Toronto, University of Toronto Press, Vol. 2, p. 1044-62.)

Beschel, R. E. 1963. Geobotanical studies on Axel Heiberg Island in 1962. (In Müller, F., and others. Preliminary report 1961-1962, [by] F. Müller and others. Axel Heiberg Island Research Reports, McGill University, Montreal. [facobsen-McGill Arctic Research Expedition 1959-1962], p. 199-2 I 5.) 
Beschel, R. E. 1965. Epipetric succession and lichen growth rates in the eastern Nearctic. (In International Association for Quaternary Research, seventh International Congress, Boulder, Colorado, 1965. Abstracts, general sessions, p. $25-26$.)

Currey, D. R. 1965. An ancient bristlecone pine stand in eastern Nevada. Ecology, Vol. 46, No. 4, p. 564-66.

Curry, R. R. 1966. Observation of alpine mudflows in the Tenmile Range, central Colorado. Geological Society of America. Bulletin, Vol. 77, No. 7, p. $77 \mathrm{I}-76$.

Hale, M. E., jr. I959. Studies on lichen growth rate and succession. Bulletin of the Torrey Botanical Club, Vol. 86, No. 2, p. $126-29$.

Hausman, E. H. 1948. Measurements of the annual growth-rate of two species of rock lichens. Bulletin of the Torrey Botanical Club, Vol. 75, No. I, p. I $16-17$.

Nydal, R., and others. 1964 . Trondheim natural radiocarbon measurements IV, by R. Nydal, K. Lövseth, K. E. Skullerud and M. Holm. Radiocarbon, Vol. 6, p. 280-9o.

Platt, R. B., and Amsler, F. P. 1955. A basic method for the immediate study of lichen growth rates and succession. Fournal of the Tennessee Academy of Science, Vol. 30, No. 2, p. 177-83.

Reger, R. D. Unpublished. Recent glacial history of Gulkana and College Glaciers, central Alaska Range, Alaska. [M.S. thesis, University of Alaska, 1964.]

Runemark, H. 1956. Studies in Rhizocarpon, I. Taxonomy of the yellow species in Europe. Opera Botanica, Vol. 2, No. 1, p. 1-152.

Sharp, R. P. 1942. Mudflow levees. Journal of Geomorphology, Vol. 5, No. 3, p. 222-27.

Stork, A. 1963. Plant immigration in front of retreating glaciers, with examples from the Kebnekajse area, northern Sweden. Geografiska Annaler, Vol. 45, No. I, p. I-22.

Washburn, A. L. 1956. Classification of patterned ground and review of suggested origins. Bulletin of the Geological Society of America, Vol. 67, No. 7, p. 823-66.

Weber, W. A. 1962. Environmental modification and the taxonomy of the crustose lichens. Svensk Botanisk Tidskrift, Bd. 56, Ht. 2, p. 293-333. 